\title{
IMPACT OF FLOOD DISASTER IN A DROUGHT PRONE AREA - CASE STUDY OF ALAMPUR VILLAGE OF MAHABUB NAGAR DISTRICT
}

\author{
Jaya Prakash Narayana Samudrala ${ }^{1}$, Sreenivas Sarma Paraitham ${ }^{2}$ \\ ${ }^{1}$ Assistant Professor, CED, MGIT, Hyderabad \\ ${ }^{2}$ Professor \& Head, CED, CBIT, Hyderabad
}

\begin{abstract}
It is rather unimaginable to think of a flood disaster in a drought prone area, as such events will be will be occurring very rarely . When they occur, people of the region may have contrasting experiences in a sequence. That apart, the socio economic conditions of the people of the region coupled with their cultural and living styles will have great influence on their disaster response as well as post disaster operations.

This paper presents a detailed report on the flood disaster occurred in the southern part of the Mahabub Nagar district during $29^{\text {th }}$ September- $1^{\text {st }}$ October, 2009, with a focus on it's effects in Alampur village and the surroundings.The socio economic conditions along with living styles of the people are highlighted and an attempt is made to assess the impact of these aspects on the disaster response and the post disaster operations. It is argued that a comprehension of these aspects will be essential in arriving at a realistic estimate of the disaster and planning of appropriate post disaster operations there on, particularly in the context of contrasting possibilities such as flood in a disaster prone area.
\end{abstract}

Key words: Drought prone area, flood disaster, socio economic conditions, post disaster operations $* * *$

\section{INTRODUCTION}

With an area of more than 18,000 sq.kM , Mahabub Nagar forms the largest district in the state of Telangana. It also has the lengthiest river coast in the state, with Krishna and Thunga Bhadra rivers touching it on the south. Yet, the district remains highly drought prone, with lowest average annual rainfall on one side and unfertile lands that are not amenable to useful agriculture on the other hand. Most of the irrigation in the district is dependent on these low rain falls or on the wells which have very low yield. It's geographical conditions( located between 160 and $170 \mathrm{~N}$, latitude and 770 and $790 \mathrm{E}$, longitudes) make it difficult to avail the sources of river water, leaving lift irrigation as an option which is quite expensive. In all, the district suffers from lack of economic development, due to sustained spells of drought over the years. This led to migration of the people in a mass scale to various other places in search of jobs. As the poor economic conditions also have bearing on education, the district also has got the lowest literacy rate and figures frequently in the news for lowest pass percentages in various examinations. Hence, most of the migrating people settle as labour in various parts of the world . Mahabub Nagar also is popularly known as 'Palmoor' and the labour from this place also got popularized as 'Palmoor Labour'.

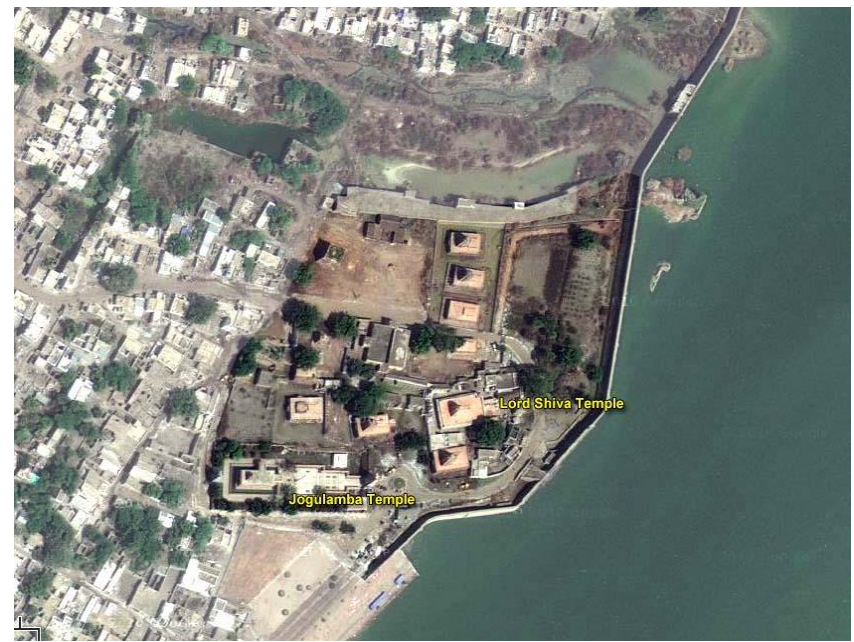

Krishna river enters the state from Karnataka through this district (Figure-1) only. At this entry point itself Indira Priyadarshini project of Jurala exists . Srisailam dam is the next project on the Krishna river on the downstream. The districts of Kurnool and Mahabub Nagar are on the down stream of Jurala and thus on the up stream of Srisailam .Tungabhadra joins Krishna near Kurnool, on the borders of Mahabub Nagar district . Alampur, a renowned pilgrimage center in the Mahabub Nagar district and a holy place of abode of the divine 'Jogulamba', a 'Shakthi Petham' ,is on the borders of Tungabhadra river, in this region (Photo-1). It's a typical village of this drought prone district with a population of about few thousands, not much of any 
business or commercial activity despite being a popular pilgrimage center ,attracting crowds only during seasonal festivals . Growing commercial crops such as cotton is a recent development as seen in other parts of the district . The place otherwise is the same reflection of the typical rural environment of the district, with majority of it's youth migrating as labour and not much of scope for any productive activity in the place. Geographically, Alampur is so located that there are possibilities, though very rare , of the backwaters of Srisailam and/or the surplus waters of Krishna and Tungabhadra hitting it during heavy downpour .

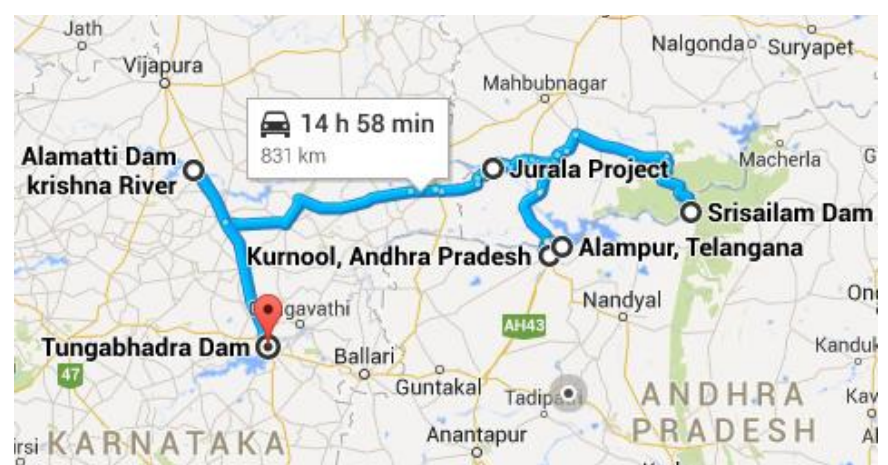

Photo-1: Google picture showing Jogulamba temple on the banks of Tungabadra

\section{THE DISASTER :}

It is very rare that the districts of Mahabub Nagar and Kurnool experience floods. This 'never in the past hundred years history' sort of disaster has occurred mainly due to the following reasons .

- An unprecedented heavy downpour during $29^{\text {th }}$ September- $1^{\text {st }}$ October , 2009 , in the upstream of the region(Northern Karnataka, Mahabubnagar and Kurnool Districts )

- Unexpected release of lakhs of cusecs of water from Alamatti followed by Joorala dam

- Probably an un-intentional non-release of water from Srisailam dam resulting in huge backwaters touching this region. It may be noted that during this period the Srisailam reservoir was poised to handle 10 lakh cusecs of water, which is the highest flood discharge in the last decade

- Added to these conditions, there was a breach in Tungabhadra reservoir at Rajoli, causing submergence of the entire Alampur, Waddepally and Manopad villages along with the Kurnool town

\section{EFFECTS OF THE FLOOD IN THE REGION :}

A total of 16 mandals covering 131 villages were effected leaving 41 villages fully submerged , 19000 houses fully damaged and over 5000 hectares of standing crops spoiled . Roads and Railways were seriously damaged making the access to the affected region all the more difficult . Thus, Alampur and surrounding regions were cut off from the world, for a while. In Alampur village, all the buildings including houses, school, hospital, post office and Jogulamba temple were totally inundated (photos 2-5) . Lot of silt got accumulated and remained so for months together , even after the disaster. Important documents in schools (photo-6, 7), Government offices , post office etc., washed away . Books and notes of school children , arogya sri cards of many patients and land patta books of farmers were among such documents. This added to the helplessness and insecurity of all the people in the region. Drainage and sanitation facilities got severely affected causing lot of health problems to the public. Women, children, elderly and disabled faced severe hardships. There was no place to stay for many families and women had no privacy. Some people were forced to use the sarees provided by aid workers for setting up their temporary shelters. Most of the people displaced due to floods have returned back to the village only to find their houses collapsed or damaged. They either moved nearer to their homes and established temporary settlements using tarpaulin sheets or moved back to shelters, relative's places with whatever remaining items left over in their houses

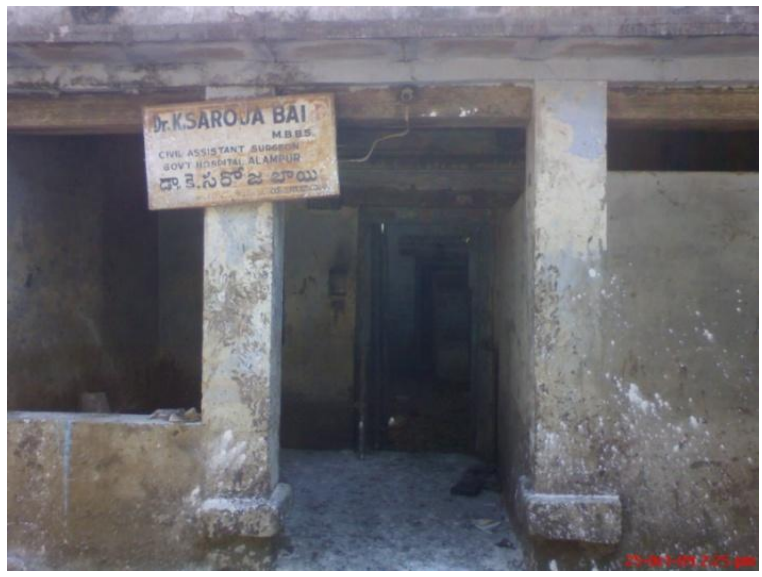

Photo 2: School building

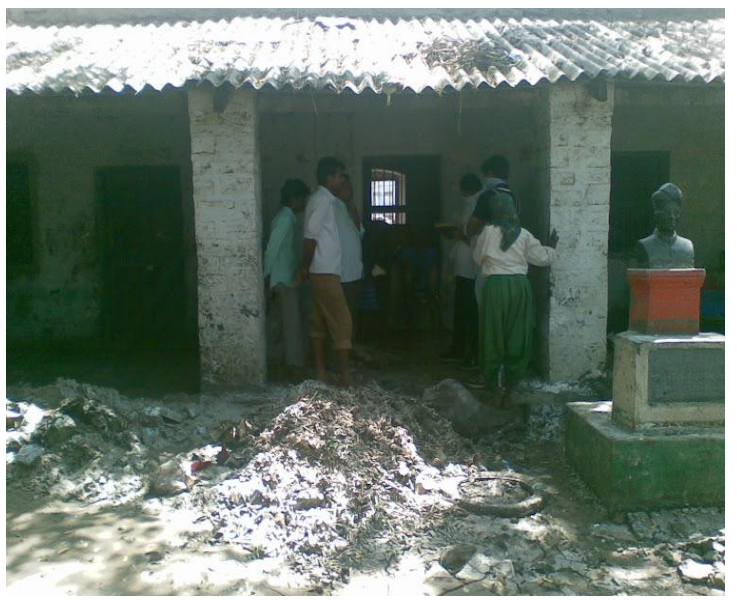

Photo 3:Hospital 


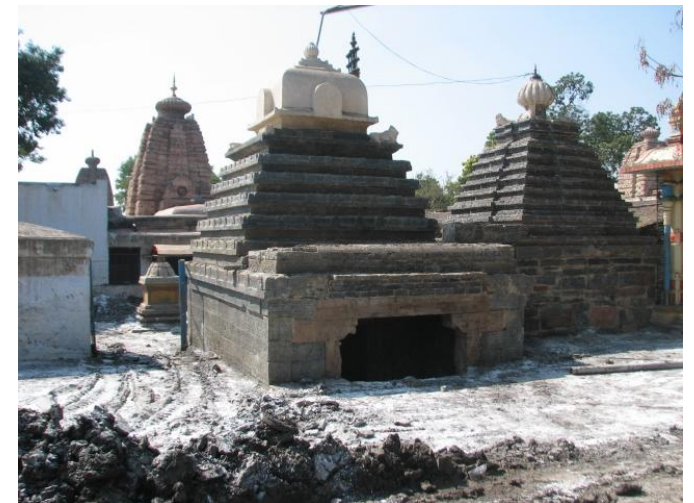

Photo 4: Silting around the temple

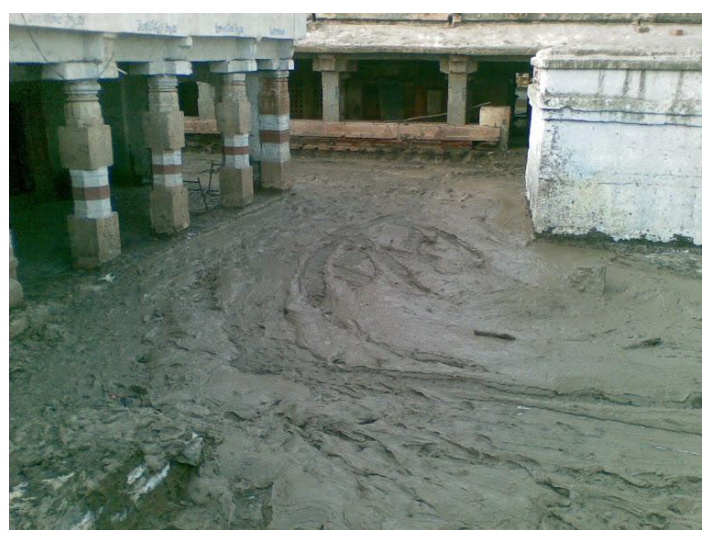

Photo 5:Silting inside the temple
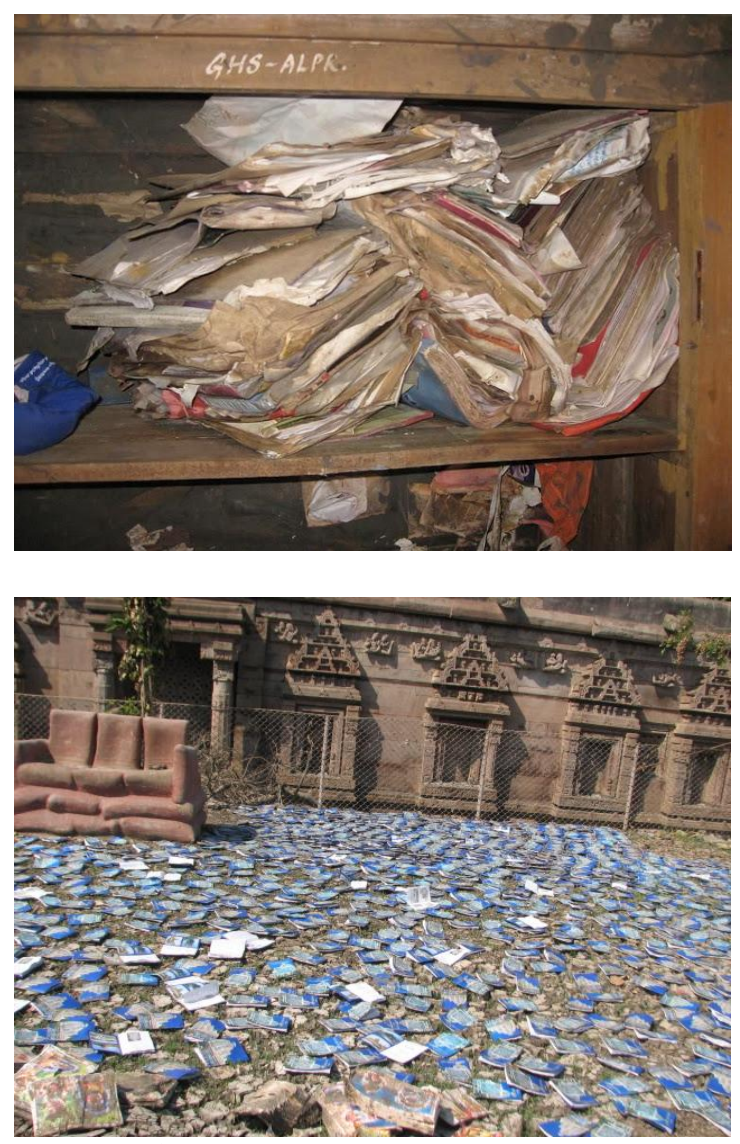

Photos- 6 and 7 :Damaged documents and books
Drinking water created a lot of problem after the flood. The hand pumps were either damaged or submerged in the flood waters. People are forced to consume flood water because there was no choice. Where flood water has receded, people were still seen using surface water for all purposes including for drinking, cleaning, bathing and washing. Surface Water was being used for livestock too. Though the government took the action to distribute the water packets in flooded area, that was in sufficient.

After returning back to their homes the flood victims of the village were facing severe acute respiratory tract (ART) infections and skin related diseases. People displaced have either moved to their relatives living in nearby towns, or to temporary camps established by the government or by themselves. These temporary shelters(photos 8 and 9) were without adequate facilities and no access to basic services like safe drinking water, toilets and solid waste disposal. It really will be difficult for anybody to get acclimatized in an unfamiliar environment, that too in an unfavourable situation.
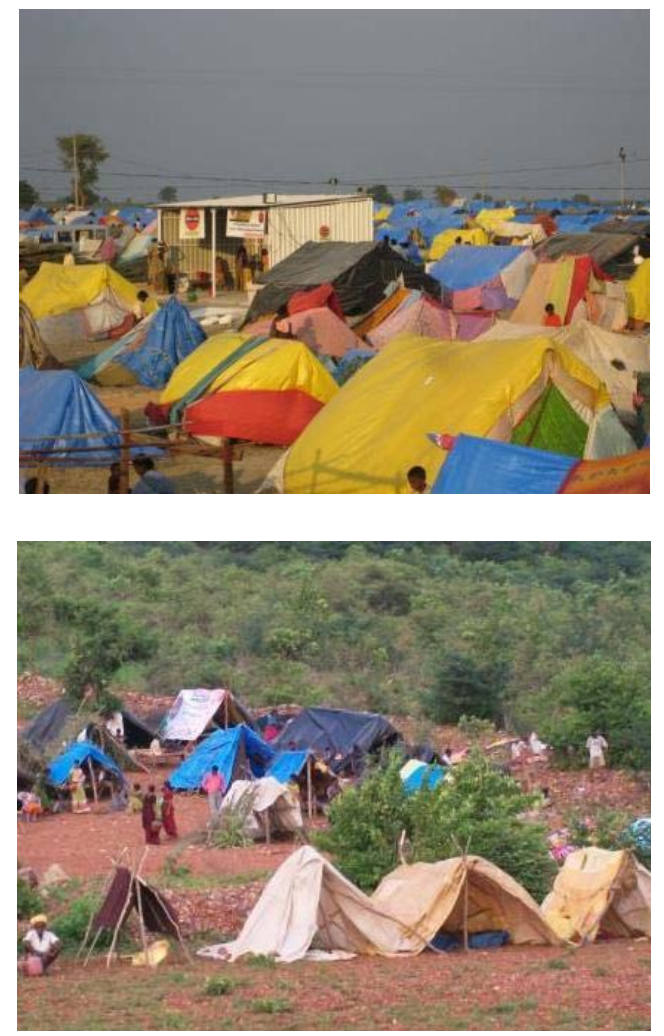

Photos 8 and 9: Temporary Shelters

\section{INFLUENCE OF LIVING}

\section{CONDITIONS AND STYLES OF THE PEOPLE:}

Being ruled by the Nizams for more than 600 years, the life style of the people of Palmoor is very much comparable to slavery . Most of the village people of this district are still living like the way people lived 2000 years ago: with a carry weight on their heads, use of bullock carts, ploughs , moping the floors with hands etc. They are cool and hard working but a majority end up as labour due to lack of education. As the opportunities are less in this region, they 
often migrate to other places . Same thing happened in Alampur village also . Most of the houses were already vacant and locked(photo 12) . This in a way reduced the casualties but was also responsible for unmaintained houses and unnoticed damage to the houses and house hold articles as well .

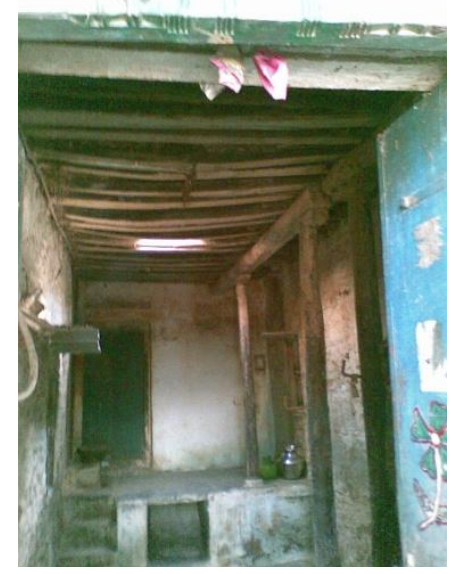

Photo 10 : CRS building in mud mortar

A majority of the houses were built in mud walls or CRS walls using mud mortar (photo 10 and 11), which are more susceptible to damage in the presence of water. Rains and floods can easily damage and even collapse such buildings . Even those buildings which survived were totally silted and de silting was a tough task in mud based buildings and mud floors. As roads were also heavily silted access was difficult in to the village to start any mechanical operations (photo 13). Even the holy Jogulamba temple was totally silted and was unusually closed without any regular worships for several days, pending the de silting operations .

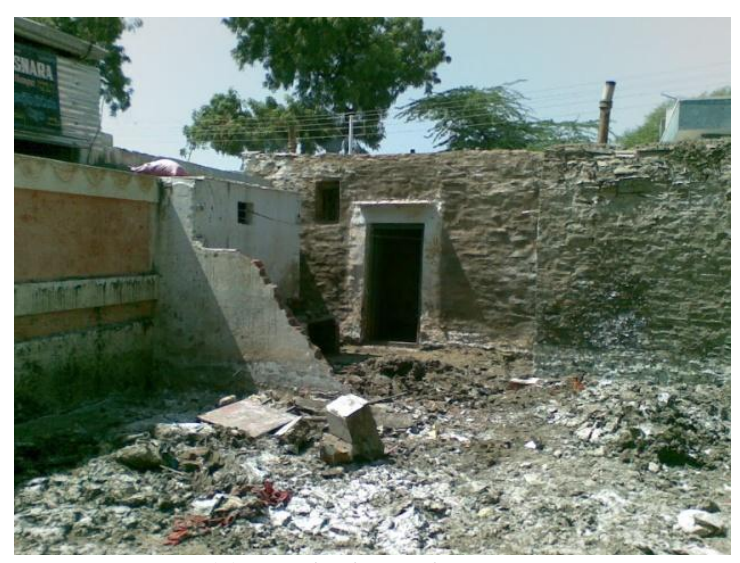

Photo 11 : Building with mud walls

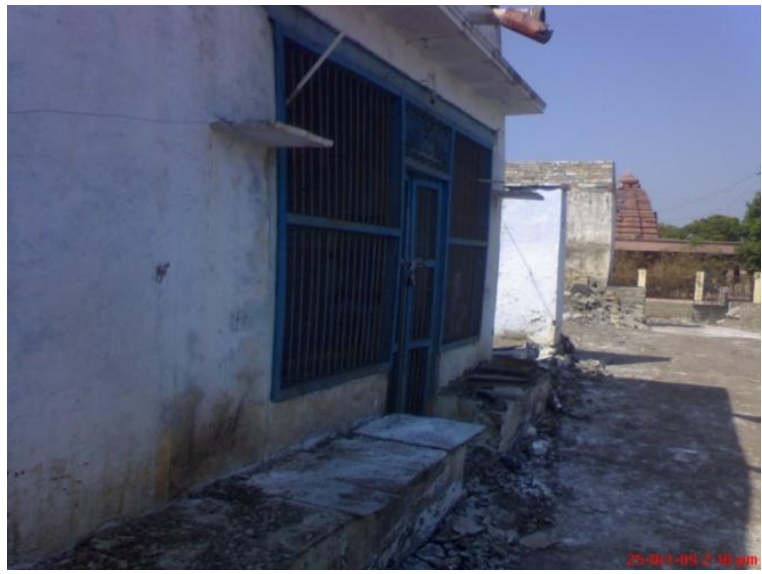

Photo12 : Locked houses even after a month

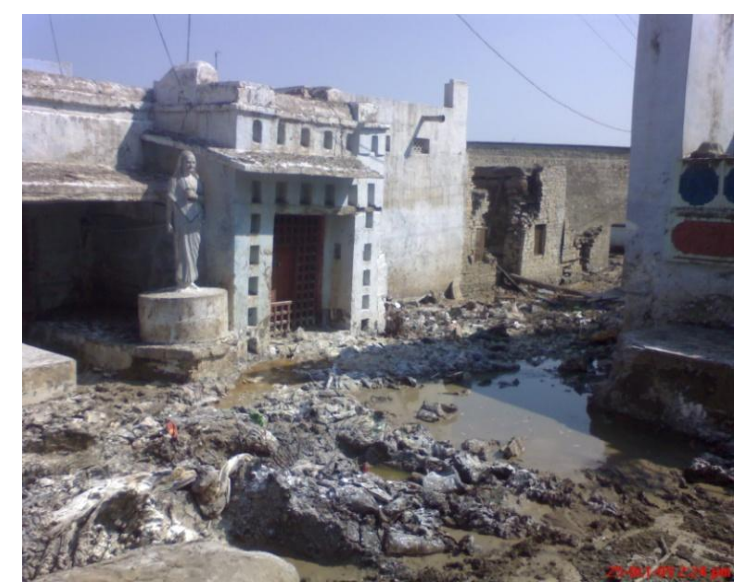

Photos 13: Roads blocked with silting

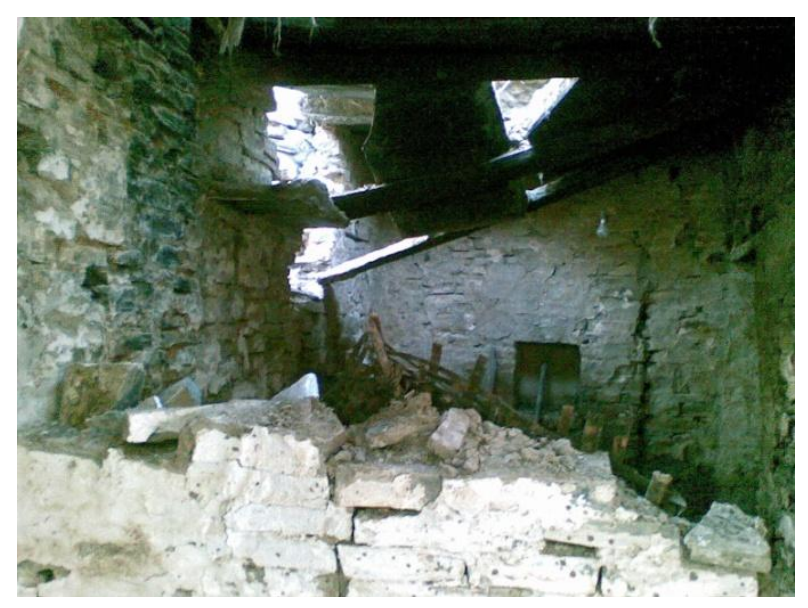




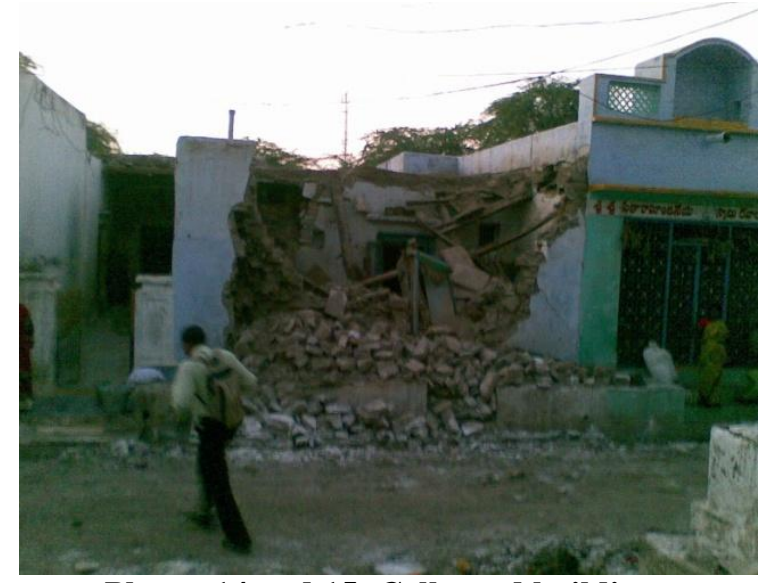

Photos 14 and 15: Collapsed buildings

Silting was a problem for the agricultural sector also . All the fields were also heavily silted, damaging the standing crops and not allowing any access to the labour (photos 14and 15). Even that opportunity of earning through agricultural labour was shut on the poor villagers of Alampur and they essentially had to quit the village in search of livelihood. It was pathetic to note that when NGOs visited the village for rendering the possible help (photo 16), only children, old people and disabled were mostly found in the village looking out for help. Another observation is that clothes donated excessively by the NGOs were seen thrown in the fields outside the village (photo 17) , as the people were mainly requiring food and shelter . Temporary shelters were created at higher levels near the village and some people could take shelter in them. Tarpaulins came to rescue for a majority.

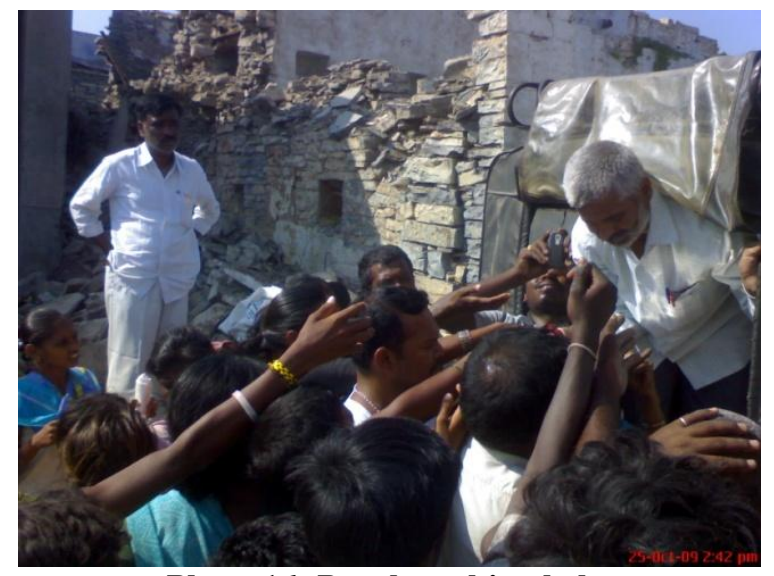

Photo 16: People seeking help

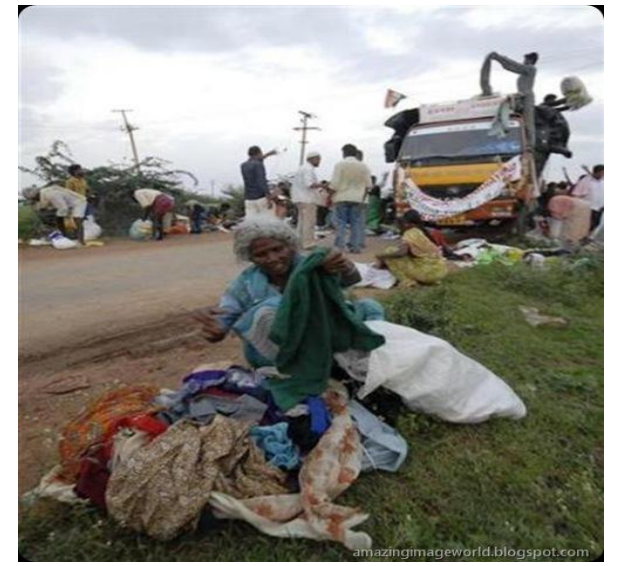

Photo 17: Fate of excessively donated cloths

The village lived in darkness for several days as it took quite some time to repair the power lines .

\section{CONCLUSION :}

The effects of any disaster in a locality will be multi-fold, if that locality is already under the spree of disasters of contrasting nature previously. A drought prone area receiving floods is the best example of such possibility . The living conditions and styles of the people living in such areas will have great influence on the effects of a disaster in that locality. An understanding of these conditions will be of immense help in deciding appropriate course of action , for disaster relief.

\section{REFERENCES:}

1). Sarma P.S.and Narayana J.P. " A report on the visit to Alampur " submitted to "TEAM for ENLIGHTENED ACTION for CHILD HEALTH, EDUCATION and REHABILITATION ( TEACHER )" , An NGO , October , 2009, Hyderabad, INDIA

\section{ACKNOWLEDGEMENTS:}

The authors profusely thank 'TEACHER', the NGO that gave the opportunity for them to visit Alampur and all the members of 'TEACHER' for their contributions and encouragement for this noble cause. They also thank Mr.Prem Raj, Tahsildar,Alampur and Ms.Akhila Prasanna, Dy.Tahsildar, Civil Supplies DSO, Mahabub Nagar, for facilitating the visit to Alampur . 